Contract Damages, Moral Agency, and Henry James' The Ambassadors

Jennifer Nadler

Osgoode Hall Law School of York University, jnadler@osgoode.yorku.ca

Source Publication:

Canadian Journal of Law \& Jurisprudence 32:2 pp. 443-471

Follow this and additional works at: https://digitalcommons.osgoode.yorku.ca/scholarly_works

Part of the Contracts Commons

\title{
(c) $(\dot{)} \Theta \Theta$
}

This work is licensed under a Creative Commons Attribution-Noncommercial-No Derivative Works 4.0 License.

\section{Repository Citation}

Nadler, Jennifer, "Contract Damages, Moral Agency, and Henry James' The Ambassadors" (2019). Articles \& Book Chapters. 2762.

https://digitalcommons.osgoode.yorku.ca/scholarly_works/2762

This Article is brought to you for free and open access by the Faculty Scholarship at Osgoode Digital Commons. It has been accepted for inclusion in Articles \& Book Chapters by an authorized administrator of Osgoode Digital Commons. 


\section{Contract Damages, Moral Agency, and Henry James' The Ambassadors}

Forthcoming in The Canadian Journal of Law and Jurisprudence

\section{$\underline{\text { Introduction }}$}

The goal of contract damages is to put the plaintiff in as good a position as she would have been in had the contract been performed. ${ }^{1}$ This principle is well settled in contract law, and yet there is a deep ambiguity about what it means. Does putting the plaintiff "in as good a position" mean that the breaching party ought to perform the contract according to its terms? Alternatively, does putting the plaintiff "in as good a position" mean that the plaintiff must be compensated for the losses caused by the breach? If the answer is the latter one, another question arises: how should the plaintiff's loss be conceived? Should the contract remedy concern itself with the plaintiff's subjective loss, measured by the plaintiff's own valuation of the promised performance? Or should compensation simply restore to the plaintiff the financial benefit of the bargain?

Traditional jurisprudence makes clear that the ordinary contract remedy is a monetary payment that compensates for the financial losses that flow from breach. ${ }^{2}$ Damages are the presumptive remedy for breach of contract; orders of specific performance are the exception, awarded only when damages are inadequate. ${ }^{3}$ Moreover, contract damages, as traditionally

\footnotetext{
I wish to thank Alan Brudner, Andrew Botterell, Chris Essert, Jason Neyers, Dan Priel, Zoë Sinel, Simon Stern, Stephen Smith, as well as the anonymous reviewer at the Canadian Journal of Law \& Juris prudence for very helpful comments on earlier drafts of this paper.

${ }^{1}$ Sally Wertheim v Chicoutimi Pulp Co [1911] AC 301.

${ }^{2}$ Parke B argued in Robinson v. Harman (1848) 1 Exch 850 at 855: "the rule of the common law is, that where a party sustains loss by reason of a breach of contract, he is, so far as money can do it, to be placed in the same situation, with respect to damages, as if the contract had been performed."

${ }^{3}$ See the speech of Lord Hoffmann in Co-operative Insurance Society Ltd. v Argyll Stores (Holdings) Ltd [1998] AC 1 and SM Waddams, The Law of Contracts, $6^{\text {th }}$ ed (Aurora, Ontario: Canada Law Book Inc, 2010) at 502.
} 
conceived, compensate only for pecuniary losses; the goal is to put the plaintiff in as good a financial position as she would have been but for the breach. ${ }^{4}$

While economic theorists have generally defended the traditional contract remedy on efficiency grounds, ${ }^{5}$ moral theorists of contract law argue that this remedy is inadequate. ${ }^{6}$ Their argument generally takes one of two forms. Some say that the traditional remedy reflects an overly narrow conception of the plaintiff's loss, one that equates loss with financial loss. ${ }^{7}$ Others claim that the traditional remedy fails to vindicate the plaintiff's right to performance of the contractual terms. ${ }^{8}$ In place of damages measured by the plaintiff's financial loss, the moral

\footnotetext{
${ }^{4}$ In British Westinghouse Electric and Manufacturing Co Ltd v Underground Electric Railways Co of London Ltd [1912] AC 673 at 689 Viscount Haldane LC said: “... he who has proved a breach of a bargain to supply what he contracted to get is to be placed, as far as money can do it, in as good a situation as if the contract had been performed. The fundamental basis is thus compensation for pecuniary loss naturally flowing from the breach ...". Lord Lloyd recognized this as the traditional position in Ruxley Electronics \& Construction Ltd v Forsyth [1996] AC 344 at 366: "Lord Haldane [in British Westinghouse] does not say that the plaintiff is always to be placed in the same situation physically as if the contract had been performed, but in as good a situation financially...."

${ }^{5}$ See Daniel Markovits and Alan Schwartz, "The Myth of Efficient Breach: New Defenses of the Expectation Interest" (2011) 97 Virginia L Rev 1939; Steven Shavell, "Specific Performance versus Damages for Breach of Contract: An Economic Analysis" (2006) 84 Texas L Rev 831.

${ }^{6}$ An apparent exception is Stephen Smith's "Performance, Punishment, and the Nature of Contractual Obligation" (1997) 60 Modern L Rev 360. Smith argues that damages are preferable to specific performance because the constant threat of court-ordered performance will make people perform their contracts for the wrong reasons - they will perform under threat of coercion rather than out of an acknowledged special bond with their contracting partner. But Smith's argument for preferring damages to specific performance depends on the assumption that "specific performance and damages are equally effective in terms of remedying the harm of breach" (at 371). However, there can be little doubt that in most cases, specific performance--because it places the plaintiff in the empirical position she would have been in had the defendant performed - is much more effective than damages in remedying the harm of breach. The challenge for a moral defense of damages is to explain why it is nonetheless justified as the ordinary remedy.

7 Judith L. Maute, "Peevyhouse v Garland Coal \& Mining Co. Revisited: The Ballad of Willie and Lucille," (19941995) 89 Nw U L Rev 1341 at 1430; Ewan McKendrick, "Breach of Contract and the Meaning of Loss" (1999) 52 Current Legal Problems 37 at 41; Ewan McKendrick, "The Common Law at Work: The Saga of Alfred McAlpine Construction Ltd v Panatown Ltd" (2003) 3 Oxford U Commwealth LJ 145 at 172; Peter Linzer, "On the Amorality of Contract Remedies: Efficiency, Equity, and the Second Restatement" (1981) 81 Columbia L Rev 111.

${ }^{8}$ Charlie Webb, "Performance and Compensation: An Analysis of Contract Damages and Contractual Obligation" (2006) 26 OJLS 41; Charlie Webb, "Justifying Damages" in Jason Neyers, Richard Bronaugh, and Stephen Pitel, eds, Exploring Contract Law (Oxford and Portland: Hart Publishing, 2009); Brian Coote, "Contract Damages, Ruxley, and the Performance Interest" (1997) 56 Cambridge LJ 537 at 542; Ewan McKendrick, supra note 7 at 147; Stephen Smith, "Substitutionary Damages" in Charles EF Rickett, Justifying Private Law Remedies (Oxford and Portland: Hart Publishing, 2008) at 93; Robert Stevens, "Damages and the Right to Performance: A Golden Victory or Not?" in Jason Neyers, Richard Bronaugh, and Stephen Pitel, eds, Exploring Contract Law (Oxford and Portland: Hart Publishing, 2009) 172; Tareq Al-Tawil, "Damages for Breach of Contract: Compensation, Cost of Cure, and Vindication" (2014) 34 Adelaide L Rev 351 at 356.
} 
critics advocate a remedy of specific performance or its closest possible approximation damages measured by "cost of cure," the cost to the plaintiff of securing a substitute performance.

In this paper, I defend on moral grounds the traditional contract law position that the presumptive remedy for breach is compensation for financial loss and the exceptional remedy is one that approximates performance. Against its moral critics, I argue that this position has a moral, not simply an economic or pragmatic, rationale. The argument proceeds in three steps. I begin by presenting a moral justification for the traditional contract principle that a plaintiff has a right to compensation for the financial loss flowing from breach but no right to performance. I do so by showing that implicit in the principle that the plaintiff has a right to financial compensation alone is a particular conception of moral agency. I try to show what is valuable in this conception although I argue that it is, in the end, incomplete. Subsequently, I consider the conception of moral agency implicit in the idea that the plaintiff has a right to performance of the contract or its closest approximation. Again, I try to show what is valuable in this conception although I argue that it too is incomplete. Finally, I suggest that the conception of the moral agent implicit in the traditional contract remedy and the conception of the moral agent implicit in the moral critique of that remedy are constituent parts of a complete conception. Once we see this, we arrive at a moral justification for a contract law that treats compensation for financial loss as the normal rule but exceptionally allows for a remedy that aims at securing performance.

How does one go about investigating what is valuable and what is lacking in a particular conception of an abstract concept such as moral agency? Such an investigation seems to require that we compare the conception to the concept in order to determine how far the conception is true or adequate to the concept, but how does one determine adequacy? Certainly, there is no 
possibility of analytically deriving the true conception from the concept, for the abstractness of the concept leaves it open to competing interpretations. Nor, obviously, should one cover up this openness by arbitrarily fixing meanings drawn from linguistic usage.

I suggest that the way to show the value and limits of a particular interpretation of an abstract moral concept is to work out the implications of that interpretation in a life lived in accordance with it. We can then ask whether those implications befit the abstract ideal with which we began. For example, if the lived implication of a certain conception of moral agency turns out to be the loss of moral agency, this would indicate a flaw in the conception and the need for revision.

If the way to test a conception of an abstract moral concept is to examine it in action, so to speak, then evaluating competing conceptions requires an act of the imagination. Specifically, it requires imagining a life lived in accordance with a particular moral conception along with the consequences - for oneself and others - of living such a life. The novelist Henry James called this imaginative act a "projected morality"8 and distinguished it from didactic literature. A work that expresses a projected morality begins, not with a moral message, but with a character who adopts a certain moral viewpoint. It then asks of that character: what will he or she do? ${ }^{9}$ In answering this question, the author must be, as James wrote, "finely aware and richly responsible"10 - aware of "the way things happen"11 and responsible to the reader's "sense of truth."12 James' novel The Ambassadors expresses a projected morality. Through its central character's (Lambert Strether's) moral development, James imagines the lived implications of

\footnotetext{
${ }^{9}$ Henry James, The Art of the Novel: Critical Prefaces (New York: Charles Scribner's Sons, 1937) 45.

${ }^{10}$ Ibid., 53 and 62.

${ }^{11}$ Ibid., 62.

${ }^{12}$ Ibid., 34.
} 
two rival conceptions of moral agency and so puts before us what is valuable and what is lacking in each one. Along with Strether, we revise our understanding of moral agency in light of its lived implications. We discover that embedded in each conception of moral agency is an insight about human beings that we cannot do without; but since each excludes the insight of the other, neither is sufficient on its own. This suggests the possibility of a conception that incorporates the essential insights of the preceding ones and so overcomes their respective limitations.

It will no doubt be surprising to find a discussion of a novel embedded in an argument about the proper remedy for breach of contract, especially when the novel is not about contracts or promises. However, the light that literature can shine on law need not be dim just because it is indirect. I argue that moral theories of the contract remedy explicitly or implicitly depend upon conceptions of moral agency and that the evaluation of these conceptions requires their imaginative elaboration. Moreover, I read The Ambassadors as an imaginative effort to answer the question: what does moral agency mean ${ }^{13}$ In that James' answer to this question engages with the rival conceptions of agency that underlie competing understandings of the contract remedy, his novel is, I hope to show, worthy of contract theory's attention. I thus interweave discussion of how The Ambassadors enacts and illuminates rival conceptions of moral agency with discussion of how those conceptions generate different views about the proper remedy for breach of contract. This interweaving allows us to see that the value and limits of each conception of moral agency underlie and explain the value and limits of each conception of the contract remedy. In the end, we arrive at a complex conception of moral agency justifying a

\footnotetext{
${ }^{13}$ Many others have found that James' novels constitute particularly subtle and insightful explorations of moral problems. See, for example, Frederick A. Olafson, "Moral Relationships in the Fiction of Henry James" (1988) 98 Ethics 294 at 298; Martha C. Nussbaum, Love's Knowledge: Essays on Philosophy and Literature (Oxford: Oxford University Press, 1992); Cora Diamond, "Henry James, Moral Philosophers, Moralism," (1997) 18 Henry James Rev 243; Robert Pippin, Henry James and Modern Moral Life (Cambridge: Cambridge University Press, 2000).
} 
contract remedy that generally aims at compensating for financial loss and exceptionally aims at approximating performance.

\section{The Moral Critique of the Traditional Measure of Damages}

Traditional contract law conceives the contractual remedy as compensation for the financial losses that flow from breach. There are two aspects to this understanding. The first is that damages, not specific performance, is the presumptive remedy. The second is that damages compensate for loss conceived in financial rather than qualitative terms; the remedy's goal is not to approximate performance but to put the plaintiff in the same financial position she would have been in had the contract been performed. Both aspects of the traditional remedy - its default to damages and its narrow conception of loss—are the object of criticism.

Recent contract law scholarship has distinguished between the plaintiff's performance interest and her compensation interest. ${ }^{14}$ The compensation interest refers to the plaintiff's interest in compensation for the monetary losses caused by breach. The performance interest refers to the plaintiff's interest in having the contract performed according to its terms. It is not hard to see why many moral theorists of contract law think that the contractual remedy ought to protect the performance interest and not merely the compensation interest. It is often argued that we have a moral duty to keep our promises and that the law of contracts enforces that duty. ${ }^{15}$ If contract law enforces a morality of promise-keeping, it would be natural to think that the contract

\footnotetext{
14 The term "performance interest" was first introduced by Daniel Friedmann in "The Performance Interest in Contract Damages" (1995) 111 LQR 628, but the distinction between the performance interest and the compensation interest comes from more recent scholarship. See supra note 8.

${ }^{15}$ Charles Fried, Contract as Promise: A Theory of Contractual Obligation (Cambridge, Massachusetts: Harvard University Press, 1981) at 17; Linzer, supra note 7.
} 
remedy should direct the defendant to keep her promise rather than allow her to pay her way out. ${ }^{16}$

Many theorists who argue that specific performance best protects the plaintiff's entitlement nevertheless recognize that this remedy may require too much court supervision or may be too burdensome for the defendant. ${ }^{17}$ However, if the plaintiff is indeed entitled to performance, then (the argument goes) we should look for a second best alternative when courtordered performance is not practically possible rather than default to compensation for financial loss. Very often second best will be damages for the "cost of cure" - the cost to the plaintiff of securing a substitute performance on the market. ${ }^{18}$

Other moral accounts of contract law arrive at a remedy geared to the performance interest, not through the duty of promise-keeping, but through the need for a broader conception of the plaintiff's loss. The exclusive focus on financial loss, say the critics, is the product of an ideology that overvalues profit maximization and undervalues other aspects of human wellbeing. ${ }^{19}$ People enter contracts, not merely to increase their wealth, but also for pleasure, security, or the satisfaction of some personal and idiosyncratic preference. ${ }^{20}$ We should therefore

\footnotetext{
${ }^{16}$ As Dori Kimel argues, this is what makes Fried's endorsement of the expectation measure of damages so puzzling. Dori Kimel, From Promise to Contract: Towards a Liberal Theory of Contract (Oxford and Portland: Hart Publishing, 2003) at 95. See also Coote, supra note 8 at 559 (arguing that the pacta sunt servanda principle supports protection of the performance interest); Linzer, supra note 7 at 138-139 (arguing that "one should stand by one's word" and the default contract remedy should therefore be specific performance); Curtis Bridgeman, "Corrective Justice in Contract Law: Is there a Case for Punitive Damages?" (2003) 56 Vanderbilt L Rev 237 at 261. Stevens also suggests that the right to performance is connected to the morality of promise-keeping in Stevens, supra note 8 at 171 and 198.

${ }^{17}$ Linzer, supra note 7 at 131 . Kimel argues that although specific performance ought to be the standard remedy, the harm principle demands that if the defendant can redress the breach equally well by paying damages, the court should adopt the measure least intrusive of the defendant's liberty. Kimel, supra note 17 at 104 . See also McKendrick, supra note 7 at 172; Al-Tawil, supra note 8 at 367.

${ }^{18}$ Webb, "Performance and Compensation," supra note 8 at 58-60; Webb, "Justifying Damages," supra note 8 at 144-149; Al-Tawil, supra note 8 at 366; Coote, supra note 8 at 542; Smith, supra note 8 at 100; David Winterton, Money Awards in Contract Law (Oxford and Portland: Hart Publishing, 2015) 174-176.

${ }^{19}$ Maute, supra note 7 at 430; McKendrick, supra note 7 at 41; McKendrick, supra note 7 at 172; Linzer, supra note 7 at $111,117$.

${ }^{20}$ McKendrick, supra note 7 at 41; Catherine Mitchell, "Promise, Performance and Damages for Breach of Contract” (2003) 2 Journal of Obligations and Remedies 67.
} 
not assume that all goods are fungible with money or that the plaintiff's total loss can be repaired by damages that reflect her financial loss. Indeed, say the moral critics, if the goal is to put the plaintiff in the position she would have been in had the contract been performed, then the loss to be compensated is not the loss that would be suffered by the ordinary market actor, but the loss actually suffered by this particular plaintiff. ${ }^{21}$ We have to ask what this plaintiff with her idiosyncratic preferences and needs has lost from her own point of view. ${ }^{22}$ Once we ask this question, we see that the appropriate remedy gives the plaintiff the very thing she bargained for and takes one of two forms - either an order of specific performance or damages measured by the cost of cure. ${ }^{23}$

The conflict between the traditional and the critical approaches to the contract remedy that I have just described has not always been recognized. For example, Charles Fried writes:

If I make a promise to you, I should do as I promise; and if I fail to keep my promise, it is fair that I should be made to hand over the equivalent of the promised performance. In contract doctrine, this proposition appears as the expectation measure of damages for breach. The expectation standard gives the victim of a breach no more or less than he would have had had there been no breach - in other words, he gets the benefit of his bargain. ${ }^{24}$

In this passage, Fried says that an award of expectation damages - which gives the plaintiff the benefit of the bargain measured in financial terms - is the equivalent of the promised performance. The suggestion seems to be that paying damages measured by financial loss is akin to keeping one's promise. ${ }^{25}$ Sometimes this is the case. Suppose manufacturer A contracts to pay

\footnotetext{
${ }^{21}$ Maute, supra note 7 at 1431; Coote, supra note 8 at 560. Robin West, Caring for Justice (New York: New York University Press, 1997) 54-55; Mitchell, supra note 21 at 68.

${ }^{22}$ Linzer, supra note 7 at 131 (arguing that the court should attend to the plaintiff's "idiosyncratic interests").

${ }^{23}$ McKendrick, supra note 7 at 39; Melvin Eisenberg, "Actual and Virtual Specific Performance, the Theory of Efficient Breach, and the Indifference Principle in Contract Law" (2005) 93 California L Rev 975; Carol Chomsky, "Of Spoil Pits and Swimming Pools: Reconsidering the Measure of Damages for Construction Contracts" (1991) 75 Minn L Rev 1445 at 1496.

${ }^{24}$ Fried, supra note 17 at 17.

${ }^{25}$ Peter Benson also suggests that damages vindicate the performance interest. According to Benson, damages and specific performance are just two different ways of giving the promisee what was promised. Damages accomplish
} 
supplier B \$10 per widget for the delivery of 10 widgets when the market price of identical widgets is $\$ 12$ per widget. If B fails to deliver, a court will order B to pay A $\$ 20$, which is the financial benefit of the bargain. Here, there seems to be no important difference between performing the contract and compensating for financial loss. This is so for two related reasons. First, it seems reasonable to assume that when B failed to deliver the widgets, A's loss was purely financial. Second, the damage award that reflects A's financial loss also enables A to go into the market and buy a substitute performance virtually identical to the one she was promised. However, two famous cases_-Peevyhouse v. Garland Coal and Mining ${ }^{26}$ and Jacob \& Youngs v. Kent ${ }^{27}$ — vividly illustrate that an award measured by financial loss may not capture the plaintiff's subjective loss and so may be insufficient to secure what the plaintiff regards as a substitute performance. These cases bring to light a fundamental question about the contract remedy that is obscured in a contract for widgets between two commercial actors. That question is whether the contract remedy should aim at compensating for financial loss or whether it should aim at approximating performance.

The Peevyhouses owned a family farm on 120 acres of land in Oklahoma. They entered into a contract with Garland Coal Company to lease a substantial portion of their land to Garland

\footnotetext{
this objective where the thing promised isn't particularized; specific performance accomplishes this objective where the thing promised is particularized. If A promises to deliver to B 10 widgets and then breaches, since the promise is to deliver any 10 widgets, a damage award that allows B to buy 10 widgets in the market for the contract price will give B what she was promised. On the other hand, if A promises B this painting, only specific performance can give B what she was promised. Peter Benson, "The Unity of Contract Law" in Peter Benson, ed, The Theory of Contract Law: New Essays (Cambridge: Cambridge University Press, 2001) 134-135. This account, however, is at odds with the law. Courts will order damages even when the thing promised is particularized, with the result that the promisee does not receive what was promised. We see this in all cases of personal service, but also in cases involving goods. In Cohen v Roche [1927] 1 KB 169, although the contract was for a particular set of chairs, the promisee's interest in the chairs was financial and the court ordered damages rather than specific performance. Semelhago v Paramadevan [1996] 2 SCR 415 suggests that damages are the appropriate remedy for breach of a contract to sell a particular piece of land so long as there is some reasonable substitute on the market. Of course, giving the plaintiff the money to buy a substitute is not the same thing as giving her the very thing promised.

${ }^{26}$ Peevyhouse v. Garland Coal \& Mining Co. 382 P.2d 109.

${ }^{27}$ Jacob \& Youngs, Inc. v. Kent, 129 N.E. 889 (N.Y. 1921).
} 
Coal for strip-mining, while Garland Coal agreed to perform remedial work on the land when the lease came to an end. Garland Coal paid the Peevyhouses royalties for the coal but failed to perform the remedial work, leaving large portions of the land unfit for use. The Peevyhouses sued for breach of contract and claimed damages of $\$ 25,000$, the cost of performing the remedial work. But the Oklahoma Supreme Court awarded them only $\$ 300$, an amount that reflected the difference between the market value of the land as it was left by Garland Coal and the market value it would have with the remedial work performed.

In Jacob \& Youngs, a builder entered a contract to build George Kent a country home. A term of the contract was that all the pipe used in the home was to come from a manufacturer called Reading. The builder built the home, but installed some pipe that was not from Reading, although it was identical in quality to Reading pipe. When Kent discovered the error, he insisted that the builder correct the mistake. This would have required the builder to demolish substantial portions of the completed structure and he refused to do so. In court, Kent claimed that he was entitled to $\$ 29,000$ in damages, the cost of ripping out the installed plumbing and replacing it with Reading pipe. Justice Cardozo rejected this claim and held that the proper measure of damages was not the cost of doing the work, but the difference in market value between a house with Reading pipe and a house with identical quality non-Reading pipe — which, of course, was zero.

In these two cases, the conflict between the traditional and critical approaches to the remedy for breach is sharp. Either the remedy's goal is to put the plaintiff in the same financial position she would have been in but for the breach, in which case Peevyhouse and Kent are both entitled only to the difference in market value between what they contracted for and what they received. Or the remedy's goal is to approximate performance, in which case both Peevyhouse 
and Kent are entitled to the "cost of cure" - the cost of obtaining a substitute performance of the term that was breached. The one solution logically excluded by this either/or is one that would give damages measured by cost of cure in one case but damages measured by financial loss in the other.

I begin with these two cases not only because they illustrate the conflict between two conceptions of the contract remedy, but also because they present a puzzle. The puzzle is that the logically excluded alternative just mentioned is the one that a widely shared intuition affirms. Most contract scholars think that the Peevyhouses were entitled to the cost of securing performance of the remedial work. ${ }^{28}$ But most think that Kent was not entitled to the cost of giving him a house with the brand of pipe he wanted, that he had a right only to compensation for his (non-existent) financial loss. ${ }^{29}$ Does this difference simply reflect the fact that we haven't fully embraced either the compensation or the performance approach to the contractual remedy so that we, without principle, sometimes prefer one and sometimes the other? Or is there a moral standpoint from which we can distinguish these apparently similar cases so as logically to allow the performance approach in one and the compensation approach in the other $?^{30}$

\footnotetext{
${ }^{28}$ Chomsky, supra note 24 at 1477; Linzer, supra note 7 at 117; West, supra note 22 at 53-54; Maute, supra note 7; Richard Wirtz, "Cost of Performance or Difference in Value" (2008) 59 Case Western Reserve L Rev 61; Bridgeman, supra note 18 at 266; Gregory Klass, "The Rules of the Game and the Morality of Efficient Breach" (2017) 29 Yale J of Law and the Humanities 71 at 107; "Professor Barrow's Peevyhouse Lecture" (1977-1978) 1 Journal of Communications and Entertainment Law xlvii.

${ }^{29}$ Chomsky, supra note 24 at 1447; Nili Cohen, "Distributive Justice in the Enforcement of Contracts" in Festschrift fuer Gunther Kuehne (Verlag Recht und Wirtschaft, 2009) at 993; Linzer, supra note 7 at 168; Alan Farnsworth, "Legal Remedies for Breach of Contract" (1970) 70 Columbia L Rev 1145 at 1173; Eisenberg, supra note 24 at 1027; Wirtz, supra note 29 at 81.

${ }^{30}$ It might be argued that the two cases can be distinguished in the following straightforward way. In Peevyhouse, the mining company knew that the Peevyhouses wanted the land repaired; in Jacob \& Youngs, the builder reasonably believed that Reading referred to quality of pipe and so did not reasonably know that Kent wanted the very thing promised in the contract. As I will later argue, this is a part of a full answer derived from a theory of contract remedies, but it is not itself the full answer for the following reason. The argument in the simple form just presented amounts to the claim that the Peevyhouses are entitled to cost of cure damages because that was an implied term of their agreement while Kent is not entitled to cost of cure damages because that was not an implied term of his agreement. But this wrongly assumes that the parties to the contract may authoritatively determineimplicitly or explicitly - the remedy for breach. The courts' treatment of penalty clauses shows that the remedy for breach comes from the law, not the parties. Further, the parties cannot contractually determine the remedy for breach
} 
I begin to answer these questions by defending the traditional measure of expectation damages - the plaintiff's financial loss. I will argue that implicit in this measure is a conception of moral agency that, although incomplete on its own, nevertheless makes a serious claim to our respect. For the illumination of this conception moral agency, I turn to James' presentation of the character of Mrs. Newsome in his novel The Ambassadors. ${ }^{31}$

\section{Mrs. Newsome and the Dignity of Detachment}

Mrs. Newsome of Woollett, Massachusetts sends her fiancée, Lambert Strether, to Paris. Strether's mission is to find Mrs. Newsome's son Chad, who has become distracted in Paris by a bad woman and bring him home to Woollett so that he can contribute to the family business from which he has benefited. In his descriptions of Mrs. Newsome, Strether seems most struck by her dignity. We have to be careful about our understanding of what dignity means here in order to understand the contrasts James draws between Woollett and Paris. In Europe, Strether notices that each person has one of "a series of strong stamps" that have been applied "from without" (44). In Europe, one's dignity is relative to one's stamp, that is, to the estate or role into which one has been born. But the Newsomes are American. They have none of the dignity of role or the honour of position. They have made their fortune in manufacturing a small article, an article so

as a matter of logic. A contractual term specifying the remedy for breach is itself a term that may be breached, and then the question for the court remains: what is the proper remedy? Thus, if Kent had included in the contract a term making clear that Reading pipe meant Reading pipe and that a breach of that term would entitle him to the money to cure the defect, this would not resolve the legal question of whether Kent was entitled to that remedy. In fact, Kent did include a contractual provision stating that defective work was to be replaced and Justice Cardozo nevertheless refused that remedy. Ultimately, the remedy for breach comes from the law, not from the parties. For the view that the answer to the remedy problem lies in the terms of the contract, see Jerry L Calhoon, "Remedies - The Measure of Damages for Breach of a Contract to Restore the Premises" (1969) 21:4 Baylor L Rev 568 and Todd D Rakoff, "Implied Terms: Of 'Default Rules' and 'Situation Sense"' in Jack Beatson \& Daniel Friedmann, eds, Good Faith and Fault in Contract Law (Oxford University Press, 1995) 191 at 207-09.

${ }^{31}$ Henry James, The Ambassadors (New York: WW Norton \& Co, 1964). References to the novel will be cited parenthetically in the text. 
trivial and lacking in dignity that Strether cannot bring himself to name it (47). And yet Strether insists upon Mrs. Newsome's dignity.

Mrs. Newsome's dignity is the dignity of free moral agency. ${ }^{32}$ She does not move through the world as a passive object of its forces, overtaken by emotion, hostage to circumstance and bodily needs. She chooses freely. Thus, Strether, speaking of Woollett and so of Mrs. Newsome, tells Maria Gostrey: “Woollett isn't sure it ought to enjoy. If it were, it would" (25). Of course, the suggestion that enjoyment could be a conclusion of duty-based reasoning is comic; but the description of Woollett philosophy makes a serious point about moral agency. The point is that, for Mrs. Newsome and the people of Woollett, human beings are not passive before pleasure, victims of causal forces, helplessly pushed around by their whims and desires. They are thinking, judging, purposive agents who can always reject impulse, refuse the pleasurable, and choose what is right. ${ }^{33}$

Mrs. Newsome not only insists that others treat her as a dignified moral agent; she treats others in this way as well by holding them responsible for their actions. Chad has a duty to Mrs. Newsome to return to the family business and add to the family fortune of which he has had the benefit, and that duty has been breached. The circumstances of the breach - the life of Paris and the woman with whom he is involved —are insignificant. To suggest otherwise — to say that there is something in Paris life that holds him there or something about the woman that makes it impossible for him to leave-is to suggest that Chad is not a free and responsible agent but a hostage to circumstance and desire.

\footnotetext{
${ }^{32}$ Martha Nussbaum takes a similar view of the significance of Mrs. Newsome's character. See Nussbaum, supra note 14 at 176-180.

${ }^{33}$ The conception of moral agency presented here is a familiar one. It finds its most carefully worked out exposition in Immanuel Kant, The Metaphysics of Morals, trans. Mary Gregor (Cambridge: CUP, 1991) and in the First Part of GWF Hegel, The Philosophy of Right, trans. TM Knox (Oxford: OUP, 1967). For Hegel, however, this conception of moral agency is incomplete.
} 
I have not yet mentioned the most striking feature of James' presentation of Mrs.

Newsome. It is that she never appears in the novel. Mrs. Newsome's absence from the novel is a symbol for the free agent's posture towards the world. Mrs. Newsome's conception of moral agency entails a certain relationship between the individual and all the things that might be chosen, between the individual and its needs, desires, and ends. ${ }^{34}$ In order to regard our choices as free, we must be able to stand back from all our particular aims, commitments, needs, and desires and view them from a position of critical detachment. We must be able to see that although they are "mine," they are not me, that although I have them, I am not them. In other words, there is a self that is prior to all the things I need, or do, or want, or pursue. There is no goal or commitment that is so central to my being that I could not detach myself from it; there is no project that could engage me in such a way that forsaking it would force an alteration of my self-understanding. It is because the individual can regard her ends from a perspective of detachment that she can regard them as freely chosen, made by her rather than making her, and herself as a free agent rather than a victim of circumstance, a passive conduit of impulse, or a receptacle of experience. ${ }^{35}$ In the novel, we see Strether eating an "omelette aux tomates," lounging in the Luxembourg Gardens, mixed-up in a Parisian affair and feeling out of control, uncertain of what to think or do. But we never see Mrs. Newsome as an embodied human being, entangled in personal relationships or embedded in a social or cultural setting. Indeed, we never

\footnotetext{
${ }^{34}$ For a parallel discussion of the relationship between the free agent and the world see Michael Sandel, Liberalism and the Limits of Justice (Cambridge: Cambridge University Press, 1998) 54 -56.

${ }^{35}$ See Hegel, supra note 34 at paragraphs 5 and 35; for an elaboration of the significance of this conception of the person for private law, see Alan Brudner, The Unity of the Common Law (rev ed with Jennifer Nadler) (Oxford: OUP, 2013). See also Peter Benson, "The Basis of Corrective Justice and its Relation to Distributive Justice" (19911992) 77 Iowa L Rev 515 at 555; Ernest Weinrib, The Idea of Private Law (Cambridge, Massachusetts: Harvard University Press, 1995) at 81 and 97.
} 
see her at all. She is for us, as she is for Strether, "all...fine cold thought" (297) - fine because an exemplar of the dignified moral agent, cold because detached from human need and desire.

So, I think it is clear that even if Mrs. Newsome could be made to see that Chad is not being held hostage or deceived by a bad woman but is rather choosing the pleasure of Parisian life with open eyes, this would not alter her conception of his duty. The famous line I have already cited, "Woollet isn't sure it ought to enjoy. If it were it would," signals a conception of morality that sharply distinguishes matters of right from matters of happiness and subordinates the latter to the former. This too is connected to Mrs. Newsome's conception of moral agency. If agency inheres in the capacity to stand back from circumstance and inclination and choose what to do, there is a sense in which each choice we finally make looks undignified. Each concrete choice to follow an inclination, gratify a desire, or satiate a need looks like a denial of the detachment that is the source of our agency. We each decide to follow this or that inclination, gratify this or that desire, satisfy this or that need - in the end, we may be happy or unhappy. But this state of happiness or unhappiness reflects an attachment to things that the moral agent must regard as an embarrassment. We thus see Strether ashamed at the joy he finds in shopping for paper and neckties, uneasy at the delight he takes in the Luxembourg Gardens, self-conscious of his failure to behold the world with the "sombre detachment" of Woollett (38). For the conception of the person that Mrs. Newsome and Woollet represent, there is no dignity in concrete choices and no moral value in the end state they produce. Moral value resides solely in the capacity for detachment, for it is that capacity alone that both constitutes and reveals our freedom.

In Mrs. Newsome, James puts before us a conception of moral agency that could be the basis for claims of intrinsic worth and equality. These two things are connected. Because moral 
agency is conceived as an abstract capacity, the dignity of the moral agent is universal and immutable. The capacity for agency cannot be lost or harmed; it is untouched by experience or circumstance. Agency is innate; we are dignified moral agents just because we are human beings with the capacity for free choice. Because, moreover, moral agency consists in an abstract capacity that is unaffected by ability or virtue, it is the same in everyone; it is therefore the basis not only of human beings' intrinsic worth but also of their equal worth. This is why Strether, though he comes to see Mrs. Newsome's philosophy as inadequate, nevertheless recognizes its moral force and insists to the end that Mrs. Newsome has "a perfection of her own" (298). ${ }^{36}$

\section{Detachment and Damages}

If we conceive of the subject of contract law as the dignified, detached moral agent that James puts before us in Mrs. Newsome, we can explain both why the traditional contract remedy understands loss narrowly as financial loss and why it is indifferent to the plaintiff's interest in performance of the promise. ${ }^{37}$ The self that is detached from any particular plans, needs, or

\footnotetext{
${ }^{36}$ In her analysis of agency in Gaskell's Ruth and Dickens' Bleak House in Liberalizing Contracts: Nineteenth Century Promises Through Literature, Law, and History (Routledge: Oxon and New York, 2018), Anat Rosenberg shows that the novelists treat abstraction as a matter of empirical isolation - they present us with characters that lack family ties, friends, a sense of institutional belonging, or meaningful work. If this is what abstraction means, then there is nothing in it that anyone could value and so Rosenberg persuasively reads Ruth and Bleak House as recoiling from abstraction. But James, I argue, treats abstraction as a conceptual rather than an empirical possibility - the possibility of distinguishing, in thought, between a self and its attachments. There is, as I think James shows us, value in this conceptual possibility and so James' novel cannot be characterized as a simple recoiling from abstraction. In Poetic Justice (Boston: Beacon Press, 1995), Martha Nussbuam argues that the realist novel's commitment to concrete particulars is itself a critique of the abstract conception of the person. Without disputing this reading of the realist novel in general, I argue that James' novel presents a more complicated picture, in which the abstract conception of agency is preserved as part of a whole rather than jettisoned. That there may nevertheless be a tension between the realist novel's commitment to particulars and the abstract conception of moral agency is symbolized by the fact that Mrs. Newsome, whose conception of moral agency is abstract, never makes a concrete appearance in James' novel.

${ }^{37}$ Others have shown that the shape of $19^{\text {th }}$ century contract law, including the contract remedy, has a historical explanation. See, for example, Morton Horwitz, The Transformation of American Law 1780-1860 (Cambridge, Massachusetts: Harvard U Press, 1977) 160-2109. But the historical explanation does not answer the separate question of whether the contract law that developed in the $19^{\text {th }}$ century has a normative justification and it is that question that I address in this paper.
} 
preferences must view her resources - money, land, chattels - as undifferentiated means for the expression of her generic purposiveness. It's only from the perspective of a determinate life plan, set of moral commitments, or system of preferences that particular things have value to us independent of their market value. It's only from within the context of a lived human life that it makes sense for someone to value a family farm more than the money it would take to buy a substitute piece of farmland, or to value a home that expresses her own aesthetic sensibility over the money that reflects the market's impersonal valuation. If we conceive of the subjects of law as persons with the capacity for setting purposes but abstracted from all particular purposes, then resources become all-purpose means - things that enable us to do whatever we might choose to do - and their value to us can't mean anything other than their market value.

Moreover, if the subjects of law are abstractly equal moral agents, then the law of contracts can force them to respect one another's capacity for choice, but cannot force them to further one another's idiosyncratic choices. This is so for two related reasons. First, whereas the capacity for choice is the locus of the moral agent's dignity and thus commands respect, concrete choices are contingent and arbitrary and so have no moral standing to coerce others. Second, because the capacity for choice is universally and identically present in all human beings, it is capable of grounding a system of reciprocal and therefore equal obligations. But concrete choices are subjective and idiosyncratic. If they are permitted to generate obligations, those obligations will be unequal. However, to force a defendant to compensate for the plaintiff's subjective loss or to specifically perform the contract is to force the defendant to support the plaintiff's concrete choices. It is to subordinate the defendant to the idiosyncratic requirements of the plaintiff's subjective happiness and is inconsistent with the dignity and equality of abstract moral agents. 
Of course, it might be objected that the breaching party is not being forced to serve her contracting partner's purposes. Contract law is, after all, the law of voluntary obligations; it simply forces the breaching party to honour her agreement to serve her contracting partner's purposes. However, if we take the view that contract law is a law for selves whose agency inheres in their independence from things, then this is not the correct view of the contractual agreement. The picture of a self detached from ends, preferences, and values informs the meaning of the parties' agreement as well as the remedy for breach. From this point of view, what the contracting parties agree to is the exchange value of their property. They agree that this painting is worth that book, or that this house is worth that amount of money. ${ }^{38}$ This agreement commands respect partly because in trading away what I possess in exchange for a promise to deliver its value, I demonstrate a capacity for independence from material things—-for treating my "stuff" as a mere locus of instrumental value for which I can always substitute something else. Moreover, as I demonstrate my capacity for independence by parting with my possession, I receive recognition of my free agency from my contracting partner, who acknowledges that she cannot simply take what I possess but must rather pay my price.

Thus, from the standpoint for which moral agency rests on detachment, a court that requires the breaching party to pay the difference between the exchange value of what was promised and the exchange value of what was received treats both parties with the dignity that is

\footnotetext{
${ }^{38}$ Kant writes: "in this reciprocal relation of choice no account at all is taken of the matter of choice, that is, of the end each has in mind with the object he wants; it is not asked, for example, whether someone who buys goods from me for his own commercial use will gain by the transaction or not. All that is in question is the form in the relation of choice on the part of both...." See Kant, supra note 34 at 56. And Brudner writes: "Where Ernest promises Michael that he will deliver 10 widgets @ \$100 and Michael promises Ernest that he will pay him $\$ 1,000$ on the delivery of ten widgets, formal right construes the agreement as one between detached (object-independent) persons to exchange values: $\$ 1,000$ in currency for $\$ 1,000$ in widgets." Brudner, supra note 36 at 192 . Benson argues that the relationship between promisor and promisee "wholly consists in their mutual recognition of one other as each having a capacity for ownership" and that the thing transferred from one party to the other must be conceived "in abstraction from the thing's particular qualitative features, and not at all in terms of its specific usefulness in relation to individual needs." Benson, supra note 36 at 593 and 595.
} 
their due. It treats the plaintiff as indifferent to particular objects, and it obliges the defendant to defer only to the plaintiff's ownership of a certain value. But a court that awards a remedy approximating performance disrespects both parties, according to this view. On the one hand, it forces the defendant to serve the idiosyncratic purposes of the plaintiff as distinct from her universal capacity for setting purposes; on the other hand, it treats the plaintiff as a being who is bound to objects of desire.

Seana Shiffrin argues that law, including contract law, "should be capable of being known and accepted by a self-consciously moral agent." ${ }^{39}$ But the question is how we should conceive of the self-consciously moral agent. For Shiffrin, the moral agent to whom law must submit for confirmation of its authority is a concrete human being with a robust moral personality, one who is committed to, among other things, fidelity and other promissory norms. ${ }^{40}$ The conception of the moral subject that I am now elaborating deliberately abstracts from this perspective. Fidelity may be an important virtue; it may even be, as Shiffrin argues, a virtue necessary for a flourishing system of justice. ${ }^{41}$ But insofar as it is a commitment rather than an innate quality of human beings, it may or may not be shared; and insofar as it is an excellence rather than an innate capacity, it may or may not be shared equally. Moreover, to adopt a conception of the moral agent that abstracts from questions of what is good or valuable (like the virtue of fidelity) is to treat the moral agent as capable of discovering for herself what is good and valuable. Thus, a contract law that assumes a moral subject committed to the morality of promise-keeping fails to treat its subjects as equally worthy of respect; it therefore could not be "known and accepted by the self-consciously moral agent."

\footnotetext{
${ }^{39}$ Seana Shiffrin, "The Divergence of Contract and Promise" (2007) 120 Harvard L Rev 708 at 712.

${ }^{40} \mathrm{Ibid}$ at 714.

${ }^{41}$ Ibid.
} 
Yet the arguments from the morality of promise-keeping that favour performing one's promise over paying damages all presuppose just such a content-filled moral subject. Shiffrin offers the example of the plumber who commits to doing a job but then fails to show up, and analyzes the homeowner's natural rage and resentment in response to that failure: she wanted the job done and not a wad of cash as compensation; she wanted this plumber to do the job and not some other plumber. She is morally indignant at this person's failure to do what she promised and at having to go through the process of hiring someone else. ${ }^{42}$ From the perspective of abstract agency, all this describes one person's subjective preference for a particular plan and there is nothing in it that law can recognize. A law that attributed significance to the promisee's annoyance — even her morally justified annoyance—at not getting what she wanted would subordinate one moral agent to the feelings of frustration or indignation of another.

For the agent free of all material attachments, there is no difference between performance and compensation measured by financial loss. But we have arrived at this assumption of indifference, not through an ideology that overvalues money or that champions efficiency over morality, but through a conception of agency that abstracts from the preferences that confer on promises a value distinguishable from their market value. Indeed, the abstract agent should be construed not merely as indifferent between court-ordered performance and damages measured by financial loss. Damages for financial loss are the only remedy appropriate to the moral agent

\footnotetext{
${ }^{42}$ Shiffrin says that we can explain and justify the resentment one feels in this situation if we see that the breaching party has usurped the non-breaching party's right to decide for herself how to spend her time by treating the nonbreaching party's time as if it were her own. With this argument, Shiffrin recasts the employer's subjective annoyance as a rights violation. But of course, this is an exaggeration - as Shiffrin admits. Every contracting party must make her own decisions about the nature and extent of her reliance on the promise. She may spend money in reliance on the promise or she may simply clear her schedule for a day. These decisions are her own and they reflect her own plans and priorities rather than an improper usurpation by another. Seana Shiffrin, "Could Breach of Contract Be Immoral?" (2009) 107 Mich L Rev 1551 at 1564.
} 
who regards all material attachments as renounceable, all preferences as changeable, and all objects as exchangeable for equivalent ones.

But now a problem arises with the view of agency personified by Mrs. Newsome. If one adopts the conception of the human being as detached moral agent, then Peevyhouse and Jacob \& Youngs look in all relevant respects the same. A judge who views the litigants in these cases as abstract moral agents will think she does no wrong in awarding both Peevyhouse and Kent the difference between their property's exchange value in its present state and its value in the state it would have been in had the contract been performed. Since the parties' freedom and moral worth inhere precisely in their capacity for detachment from material things, their freedom and worth are fully respected if they are treated as generic property owners for whom one piece of land is as good as any other of equal value in the market. In both cases, an award compensating for lost market value fully compensates for the losses that selves unencumbered by specific attachments would suffer. By contrast, to award Peevyhouse the cost of returning his farmland to usable pasture would subordinate the owners of the mining company to the Peevyhouse's subjective preference for a particular piece of land. To award Kent the cost of replacing the existing plumbing with plumbing from his preferred factory would subordinate the builder to Kent's idiosyncratic fixation on a particular kind of pipe.

However, if one thought the result in Peevyhouse was wrong, if one thought it was wrong to treat the Peevyhouses as indifferent between their family homestead and some other piece of property, one might be moved by the arguments of those who have been deeply critical of the conception of the person as abstract moral agent. ${ }^{43}$ Indeed, once in Paris, Strether, though sent as

\footnotetext{
43 These arguments are well-known. Michael Sandel argues that the self is at least partly constituted by its ends and that agency is a process of self-discovery rather than self-creation in supra note 35 at 161-5; Alasdair MacIntyre argues that the self is embedded in communal roles that constitute its moral starting point in After Virtue (Notre Dame: University of Notre Dame Press, 1984, c1981). The idea that the abstract conception of the moral agent fails
} 
the ambassador of Mrs. Newsome's moral judgment, becomes just such a critic of her philosophy.

\section{Lambert Strether and the "Virtuous Attachment"}

Whereas Woollett is all "fine cold thought," Paris is "warm with life" (80). When

Strether finds Chad in Paris, he discovers that Chad is transformed, improved, a "gentleman" (89); the bad woman who has supposedly entrapped him, Madame de Vionnet, is magnificent. Strether, sent to Europe to bring Chad home, finds himself pleading with Chad to stay in Paris. Something has clearly gone wrong.

What has gone wrong is that in Paris, Strether realizes that he has failed to live--failed, that is, to live a life that reflects his own sense of what makes life worth living. He has failed to live a life devoted to culture, great literature, and art; he has failed to sustain any meaningful relationships. His life has been a "wreck of hopes and ambitions," a "refuse-heap of disappointments and failures" (51). He thinks of his work for Mrs. Newsome as work in a prison house. In Chad's Paris home, by contrast, Strether finds that "freedom was what was most in the place" (281): "[h]is changed state, his lovely home, his beautiful things, his easy talk...what were such marked matters all but the notes of his freedom?” (104).

Strether's new feeling of contrast between his own life and Chad's signals a changed conception of moral agency. For the difference between Strether and Chad is that Chad is living a life in accordance with tastes and ideals that are his own. Chad's life evinces, not a detachment

as a description of human beings is also central to feminist thought. See, for example, Seyla Benhabib, Situating the Self: Gender, Community, and Postmodernism in Contemporary Ethics (New York: Routledge, 1992) 152; Ngaire Naffine, Law's Meaning of Life: Philosophy, Religion, Darwin, and the Legal Person (Oxford and Portland, Oregon: Hart Publishing, 2009); Robin West, "Jurisprudence and Gender," (1988) 1 University of Chicago L Rev 1 at 2; Jennifer Nedelsky, "Reconceiving Autonomy: Sources, Thoughts and Possibilities," (1989) 1 Yale J of Law and Feminism 7 and Jennifer Nedelsky, Law's Relations: A Relational Theory of Self, Autonomy, and Law (Oxford: Oxford University Press, 2011) 9-30. 
from the material world, but a self-authored attachment - a life of concrete choices and commitments that reflect a thought-out scheme of preferences and values. The conception of agency as the capacity for detachment thus "turn[s] false" 44 for Strether, for that capacity is consistent with a life lived as the ambassador of Mrs. Newsome's projects and interests, and reflecting none of his own.

Strether's changed view of moral agency entails a changed view of what is salient for judgment. Whereas Mrs. Newsome judges right and wrong from a standpoint that abstracts from individual need and desire, Strether now seeks understanding by immersing himself in Chad's point of view. To understand Chad's entitlements and obligations, he must understand the choices that Chad has made, and see those choices as Chad sees them. Thus Strether finds that he and Chad are part of an "inclusive relation" (108), a relation the narrator describes as Strether's “deep immersion" in a "fathomless medium" (108). This is most evident in Strether's relationship with Madame de Vionnet, in the way he seems to fall in love with her himself. Thus, the water imagery, suggesting immersion in another's point of view, multiplies when Strether speaks with Madame de Vionnet. He has a sense of himself "plunging" (174), of "letting himself go...diving deep," (176). Falling under the spell of Paris, falling in love with Madame de Vionnet, Strether seeks judgment by sympathetically immersing himself in Chad's point of view, by thinking as Chad thinks, feeling as Chad feels.

The judgment that Strether comes to is this. Chad's choices have more for their content than arbitrary whims and momentary inclinations. Whereas attachments to persons and things are undignified in Mrs. Newsome's world-view, Strether now believes that Chad has formed a "virtuous attachment." He has not been ensnared or deceived by a bad woman; he has committed

\footnotetext{
${ }^{44}$ James, supra note 9 at 314.
} 
himself to a "high fine friendship" with Madame de Vionnet, a married woman estranged from a husband who mistreated her. This friendship has shaped Chad's identity and given purpose to his life. Thus, for Strether, Chad's attachments are moral attachments. They are expressive of his agency and so have a dignity and value that others must recognize. It would be wrong to insist that Chad give up Paris to return to the family business, for that would be to insist that Chad forsake his freedom, now understood as the freedom of a self-authored life.

\section{Contracts and Attachments}

We can understand the various criticisms of the traditional measure of contract damages as embracing, in different ways, the lesson that Strether learns in Paris. The lesson is that moral agency is not a capacity for detachment from all objects of choice, for that capacity may have no worldly reality. Moral agency is rather the commitment to the concrete projects and goals that make our lives our own. The determinate individual trying to shape a life for herself cannot stand aloof from all ends, values, and attachments. Rather, she must commit to ends and values chosen upon reflection, form attachments to other human beings, embrace these ends, values, and attachments in a plan of life that becomes a part of her identity. Thus, the subject of contract law is not a philosophical abstraction but a concrete human being who must shape her life so that it reflects her own considered view of what is important. Her concrete choices, because they further self-formed projects expressive of her moral agency, are worthy of legal recognition.

Once we view the individual from within her moral commitments and plan of life, we must attend to why concrete human beings enter contractual arrangements rather than impute reasons based on a legal construction of the person. Concrete individuals do not enter contracts to gain recognition of their capacity for detachment and they are not merely interested in 
increasing their all-purpose means. They enter contracts for goods and services that contribute to what they think is a good human life. When it comes to compensation for breach, a court should thus ask itself a broad question about how the contract was supposed to foster the plaintiff's overall well-being and then assess her damages accordingly.

Moreover, as we expand our understanding of the plaintiff's loss to include frustrated aims and preferences that are not financial, monetary compensation will seem inadequate. If someone bargains for a home that suits her aesthetic taste, in a neighbourhood where she feels a sense of belonging, she wants that home, not an amount of money that reflects its market value. If a collector of curiosities bargains for the purchase of a pair of china jars that are, in his eyes, of "unusual rarity, beauty, and distinction," $" 45$ he wants those china jars; from his point of view, from within his perspective as a collector of such objects, they are unlike anything else on the market.

As we've seen, the moral critique of the contract remedy may take a different form. It may argue, not that we need a more individualized and contextual conception of loss, but that the plaintiff has an entitlement to performance regardless of the losses breach has caused. This is Shiffrin's argument. ${ }^{46}$ On her view, the subject of contract law is a concrete subject with firm moral commitments rather than an abstract moral agent. One of the subject's moral commitments is that promises ought to be kept. Shiffrin argues that although the law should not enforce morality directly, it nevertheless must be compatible with the flourishing of the moral agent - that is, the agent who conceives of herself as subject to moral as well as legal norms. Of course, the moral duty to keep one's promise is not discharged by supplying the financial equivalent of what was

\footnotetext{
${ }^{45}$ Falcke v Grey (1859) 4 Drew 651.

${ }^{46}$ Shiffrin, supra note 40; see also Webb, "Justifying Damages," supra note 8 at 139; Kimel, supra note 17 at $99-$ 100, 108; Winterton, supra note 19 at 181.
} 
promised. ${ }^{47}$ Therefore, specific performance or some remedy that approximates it is necessary, not because it is the best way to compensate for loss sustained, but because it is the remedy that conveys the message that breach of contract is morally wrong rather than subject to a price.

For the moral theorists of contract law, the interaction in which the promisor promises some particular thing in exchange for consideration commands respect not merely because of the capacity for choice or detachment that it evinces; the particular choice the interaction embodies also commands respect, thus entitling the promisee to the very thing she was promised. Here we see an implicit expression of the view that moral agency consists, not in an abstract capacity for choice detached from all particular choices, but in choosing something in particular; for, it is only on this view that I could have, as Charlie Webb insists, a right to demand of the defendant: "do what you said you would do." 48

The moral critics of the traditional measure of damages not only share Lambert Strether's new conception of moral agency; they often appear to share his related view of the perspective that is salient for judgment. For just as Strether immerses himself in Chad's perspective, so the critics frequently insist on the moral importance of the subjective perspective of the victim of breach. This is because attributing moral value to concrete choices means that we must consider the plaintiffs' subjective losses - their losses, not as abstract property owners, but as unique individuals with particular attachments, preferences, and life plans. ${ }^{49}$ And if we are committed to viewing the plaintiffs in this way, then we must, as some have argued, take an approach to contracts that focuses on context and personal narratives. ${ }^{50}$ Indeed, this is just what scholars have done with

\footnotetext{
${ }^{47}$ Shiffrin, supra note 40 at 722.

${ }^{48}$ Webb, "Performance and Compensation," supra note 8 at 57.

${ }^{49}$ Webb writes: “...the measure, and indeed the very existence, of a loss follow from and will be determined by our preferences and objectives. Because these vary from person to person, loss is necessarily personal or subjective." See Webb, "Justifying Damages," supra note 8 at 160.

${ }^{50}$ Maute, supra note 7 at 1388; Linzer, supra note 7 at 131.
} 
the Peevyhouse case. Outraged at the court's cold indifference, they have unearthed the entire background tale of the Peevyhouses' suffering. ${ }^{51}$ The Peevyhouses' loss is that of a family whose history is tied to this farm; it is the loss of the enjoyable use of their family homestead. Or recall Shiffrin's example of the homeowner frustrated by the plumber's failure to show up. The moral difference between performance and payment is illuminated by a story that shows what breach looks like from the perspective of the moral agent committed to promissory morality. Looked at from her point of view, it is impossible to suppose that she is indifferent between a kept promise and a wad of cash.

Earlier we saw that, for all its virtues in treating moral agents as equals, the conception of agency as capacity for detachment fails to see any relevant difference between the Peevyhouse and Jacob \& Youngs cases, contrary to a widely shared intuition that they are importantly different. It sees both cases (awarding damages for financial loss) as rightly decided. But the same problem must be ascribed to the conception of agency as self-authorship, though from this perspective both cases appear wrongly decided. Once we attribute moral value to the subject's concrete choices and commitments, a measure of damages based on the property's market value with and without performance appears to be the wrong remedy not only for Peevyhouse but also for Kent. In Peevyhouse, compensation for lost market value ignores the Peevyhouses' attachment to their land and fails to recognize the subjective loss they suffered from breach. In Jacob \& Youngs, compensation for lost market value fails to recognize Kent's attachment to Reading pipe. We don't know why Kent wanted pipe from this particular factory. ${ }^{52}$ But if we attribute moral significance to the fact that this was his preference or if we focus on his right to

\footnotetext{
${ }^{51}$ Maute, supra note 7 at 1341.

52 Richard Danzig, The Capability Problem in Contract Law: Further Readings on Well-Known Cases (Mineola: The Foundation Press, 1978) 120.
} 
promissory fidelity, why he wanted Reading pipe is immaterial. For whatever reason, the contract stipulated Reading Pipe and a theory that insists upon a moral right to performance will insist that Kent's entitlement, like Peevyhouse's, is to receive what he was promised, not merely a sum of money that measures his financial loss.

Perhaps then we should give up the intuition that the builder should not be made to pay $\$ 29,000$ to replace the pipe he accidentally installed with identical quality Reading pipe; perhaps, when it comes to the remedy for breach of contract, we should take up the plaintiff's point of view and ask what she has lost from the perspective of her own history, desires, commitments, and emotional bonds; perhaps we should finally rest with the philosophy of Paris and abandon the philosophy of Woollet. If we did this, would anything significant be lost? James suggests that the answer is yes.

\section{Judgment and "Virtuous Attachments"}

As I have noted, Strether comes to the conclusion that Chad and Madame de Vionnet have a relationship he describes as a "virtuous attachment" (165). Strether's judgment is thus that the obligation to return home that Chad owes his family, though prima facie binding, is not binding in the particular case. This is because the relationship between Chad and Madame de Vionnet is a moral relationship, and it therefore generates its own claim to respect. But what I have not yet noted is that James makes it clear to the reader that Strether, immersed in Chad's perspective, has not been judging well.

The difference between the judge and the person being judged must be their respective points of view. We may call the point of view of the one judged a purely personal point of view, for what she observes and values from this viewpoint will be shaped by her subjective interests. 
We may also call it the perspective of private rationality, for within it the individual sets ends for herself and decides how best to pursue them. The consciousness of the individual stands at the centre of a world $-a$ world, not the world, for the world I look at from this viewpoint is mine. As I look out at the world from this vantage point, certain things will seem good and valuable to me; certain things will give me reasons to do things. As I formulate ends and try to realize them, as I reflect upon the way their realization may conflict with the ends of others, it will make a difference to me that my ends are mine. This will give them a special importance, for from the personal point of view, I occupy a special place in the world.

However, if judgment is to be distinguished from the partiality of point of view, the judge must step back from this personal perspective and take as her object the relationship between that perspective and the world of which it is merely a part. ${ }^{53}$ From the judge's point of view, no single individual stands at the world's centre; the individual appears as one person among many and counts as one and only one. But contact with Chad "elbowed out of Strether's consciousness everything but itself" (108), and Strether, immersing himself in Chad's perspective, cedes the standpoint that treats the individual as one among others and that makes possible the distinction between judgment and point of view.

There are many clues that Chad is mistreating Madame de Vionnet. Strether's friend Maria warns him that Chad wants to "sink" the woman he's with (107) and Chad's friend Little Bilham tells Strether very early on that Chad cares less for Madame de Vionnet than she cares for him (168). When Madame de Vionnet tells Strether that Chad is "capable of anything," Strether responds, "Oh he's excellent." She is trying to tell Strether that she is vulnerable, that Chad will hurt her, but Strether does not hear it. To see that one human being's flourishing

\footnotetext{
${ }^{53}$ Nagel, The View from Nowhere (Oxford: Oxford University Press, 1986) at 4.
} 
comes at the expense of another is to adopt a standpoint that treats them as equals. But Strether takes up Chad's viewpoint and so sees only the beauty of Chad's life in Paris. He cannot see that Madame de Vionnet is being used.

The novel's concluding chapters begin as Strether spends a day by himself in the French countryside. As he sits at a country inn overlooking the river, a boat comes into view. There is a couple in the boat; they are happy and familiar with the place. As they approach the landing spot at the inn, Strether is taken by surprise. He knows the couple: it is Chad and Madame de Vionnet. It is clear that they are out of Paris not just for the day, and so Strether discovers that they have been lying: they are adulterous lovers and not merely friends. The shock for Strether is profound. The discovery that Chad and Madame de Vionnet have been lying is the discovery that the three have not been part of an "inclusive relation" after all; their lie reveals Chad's and Madame de Vionnet's independence from Strether's moral interpretation of their life together and, correlatively, Strether's detachment from them.

But this sudden recognition of his detachment from Chad and Madame de Vionnet makes possible a deeper realization. For now Strether sees that the relationship is not virtuous, not only in the sense that it is adulterous, but in the deeper sense that Chad has not committed himself to Madame de Vionnet in the way that Strether believed. Now Chad strikes Strether as "restless" (340) and Strether is horrified at Chad's reference to "satiety as a thinkable motive" for leaving Madame de Vionnet (337). Now an outsider, “detached and deliberate," Strether insists upon Chad's duties to Madame de Vionnet: "You owe her everything...You've in other words duties to her, of the most positive sort; and I don't see what other duties - as the others are presented to you — can be held to go before them" (338). Leaving Madame de Vionnet, Strether now argues, will make Chad a "brute" (335), a "criminal of the deepest dye" (336). The language of "duty" 
and "criminal" is the language of Mrs. Newsome and Woollett. It is the language of moral responsibility, insisting that we are moral agents who can stand back from our impulses, choose our actions, and be held accountable for them.

James is here suggesting to us the connection between judgment and the view of human beings as abstractly free moral agents capable of choice and responsibility. We can spell out the connection more concretely. First, judgment depends upon a conception of moral agency, for to judge someone's actions is to assume that they are the actions of a free agent and not merely manifestations of causal forces. But the assumption of free agency that's needed to make judgment possible constrains the form that judgment must take. If human beings are free moral agents, each equally capable of choice, then no agent can legitimately be subordinated to the choice of another. Thus, judgment must be objective in the sense that it must issue from a perspective that all could share; it cannot be the private perspective of any one. But the effort to find a viewpoint that all could share seems to require that we strip away everything that might differentiate human beings — their different needs, desires, and goals — and retreat to the bare capacity for choice as the one thing that human beings share just in virtue of being human beings. Thus, it seems that it is only by judging human beings from this position of detachment that we can arrive at a judgment that will not subordinate one person to the private preferences, values, or goals of another. It is therefore from this position alone that Strether can finally see that Chad is using Madame de Vionnet, who is to be sacrificed for the sake of Chad's restless freedom. And it is from this position alone that Strether can see that this is wrong.

All this sounds very much like the philosophy of Mrs. Newsome. Is Strether, in the end, her ambassador after all? I do not think so. The meeting during which Strether tells Chad that 
leaving Paris will make him "a criminal of the deepest dye" is preceded by a meeting with Madame de Vionnet herself. Here Strether finally understands the nature of their relationship.

It was of Chad she was after all renewedly afraid; the strange strength of her passion was the very strength of her fear; she clung to him, Lambert Strether, as to a source of safety she had tested... With this sharpest perception yet, it was like a chill in the air to him, it was almost appalling, that a creature so fine could be, by mysterious forces, a creature so exploited. ...He presently found himself taking a long look from her, and the next thing he knew he had uttered all his thought. "You're afraid for your life!" (322).

There is detachment and distance in the narrator's description of Strether's final, full vision. In this vision, the lovers' particular history is "strange," "mysterious" to the outsider, the distant judge. And Strether doesn't think about the agony of Madame de Vionnet's romantic love. He thinks of her abstractly, as a "creature exploited." This mode of judgment may look very much like Mrs. Newsome's, but there is an important difference.

Although Strether distances himself from Madame de Vionnet's particular point of view, he remains deeply concerned with her suffering. Madame de Vionnet finally represents, for us and for Strether, a life in which the potential for self-authorship has been thwarted. She is a picture of human passivity and vulnerability, a receptacle of ancient tradition and victim of the manipulations of others. In Madame de Vionnet we see that the abstract capacity for agency coexists in human beings with a vulnerability to forces beyond our control. Although we can each, in thought, achieve the distance from need and circumstance that agency requires, there is a sense in which our needs and our circumstances shape who we are and what we can become. In her relationship with Chad, Madame de Vionnet has trusted the shape of her life to one who treats her as a tool of his purposes. Chad is "a success" (184), but his flourishing has come at Madame de Vionnet's expense; thus, she reminds Strether, in the novel's final pages, of Madame Roland, a victim of the Reign of Terror (317). 
Strether's response to Madame de Vionnet's despair, "[y]ou're afraid for your life," seems at first out of place, for it calls to mind bodily human needs such as health or bodily integrity. But in Strether's language, "your life" means something like "your ownership of your life." Strether sees that Madame de Vionnet's suffering is not merely subjective or idiosyncratic; it is an instance of the frustration in a particular life of the potential for self-authorship. Seeing her suffering, seeing that she is afraid for the shape of her life, Strether commits to doing what he can to make Chad stay.

At the novel's end, Strether does not remain in Paris. He returns to Woollet, but with a transformed philosophy. We can articulate that philosophy in the following way. Moral agency inheres in the abstract capacity for choice and detachment, making us neither the playthings of nature nor the passive receptacles of ends externally given. This is the conception of moral agency that allows Strether to insist upon Chad's duty to Madame de Vionnet, to insist that Chad can distance himself from his inclinations and desires and do what is right. It is also the conception of agency that allows us to see Chad and Madame de Vionnet as equals even though they are unequal in all the concrete ways that differentiate human beings; it is the conception of agency that allows us to say that even if Chad's flourishing depends on the sacrifice of Madame de Vionnet, it is nevertheless wrong for Chad to use her in the way he has.

But although we can't do without this conception of human agency, it is incomplete. Taken on its own, it reduces the individual to a metaphysical possibility and so fails to treat her as a determinate human being with a life she can deliberatively shape. As Strether has discovered in Paris, our choices need not simply be dictated by the impulses and whims we find in our makeup or by an unreflectively adopted tradition. Some choices may be the product of deliberation and reflection; some choices constitute the commitments and attachments that 
express a thought-out conception of who we are and what we think is valuable. These choices are the way the capacity for agency is realized in a concrete life; they are actualizations of the potential contained in the capacity for detachment from natural impulses and their objects. And so the rational and deliberative choices of the individual shaping a life for herself are not a matter of moral indifference. They have moral standing and command the judge's respect.

But not only are the deliberative choices of the concrete individual worthy of respect; they are worthy of the judge's concern. Unlike the bare capacity for agency, a self-authored life is not innately ours and is not invulnerable to external forces. A self-authored life is a good we each try to realize in our lives. But our efforts may be thwarted by circumstance or undermined by the carelessness or manipulations of others. Accordingly, the realized agency of determinate human beings requires the judge's positive support and not merely his respectful detachment. This is why Strether comes to realize that he must "serve" Madame de Vionnet "to the end" (323); he must commit himself to supporting her dignity and caring for her well-being. At the novel's conclusion, the "virtuous attachment" lies, not in the relationship between Madame de Vionnet and Chad, but in the relationship between Madame de Vionnet and Lambert Strether.

\section{The Remedy for Breach of Contract}

I have argued that in The Ambassadors, James puts before us a conception of moral agency as both abstract and concrete, immutable and vulnerable. This conception makes a serious claim to our attention, for, as I'll now argue, it justifies compensation for financial loss as the ordinary remedy for breach of contract as well as the exceptional status of remedies that approximate performance. 
Beginning from the idea that respect for human beings as free moral agents requires a perspective that abstracts from all particular preferences and attachments, we assume that the subjects of contract law are capable of detachment from all material objects and therefore view their holdings as undifferentiated all-purpose means. They are thus assumed to be indifferent between contractual performance and its agreed upon value in money and are therefore assumed to be fully compensated for breach by a damage award measured by their financial loss. We do not make this assumption because we think that money is the only thing of value or because we prize economic efficiency over moral agency. Rather, we do so because we recognize that treating human beings as free choosers capable of detachment from objects of desire is how we treat human beings with the respect they deserve in three related ways.

First, the capacity for detachment from material objects reveals a self that is prior to all the things that might be chosen or valued. It reveals a self distinguishable from the realm of instrumental value, a locus of intrinsic value that is innate and immutable. Second, the capacity for detachment reveals an objective point of view and a basis for human equality. In viewing human beings as abstract moral agents, we abstract from all the ways they differ to the one thing they have in common just in virtue of their humanity. Moreover, in adopting the abstract point of view, we refuse to subordinate one to another by forcing her to further a preference, or goal, or value that she may not share. Finally, by adopting a standpoint that abstracts from any particular conception of what is good or valuable, we recognize each individual as a separate centre of selfdetermining activity, entitled to judge for him or herself what is good and valuable.

It is important to emphasize that the reasons for adopting the standpoint of abstract agency are normative, not empirical. Many have pointed out that when ordinary people enter into contractual agreements, they do so with the expectation that they will receive performance, not 
compensation for non-performance. ${ }^{54}$ Others have pointed out that individuals are rarely indifferent between performance of the contractual terms and the payment of damages. ${ }^{55}$ But the standpoint of abstract agency is not intended as an account of our ordinary experiences as individuals who contract with other individuals. It is thus no argument against the abstract standpoint that it fails to capture how people actually think about what they are doing when they enter into contractual agreements. This standpoint does not deny that the empirical human being has a system of desires and preferences and a set of attachments and commitments that give shape and meaning to her life. The abstract standpoint says that our freedom entails the possibility of abstraction from these things and that this possibility of abstraction is the one thing that is non-contingently shared. The idea is that law, if it is to treat human beings with the equal dignity that is their due, must view them as abstract moral agents, even though this is not, of course, the view most human beings take of themselves.

This story, however, is incomplete. It is true that some concrete choices have, as the abstract conception of agency assumes, nothing for their content but passing inclinations or unreflectively accepted custom. We see choices of this kind in The Ambassadors. Mrs. Newsome was right about Chad after all. Strether finally realizes that Chad is restless, like a "pendulum," with "sharp jerks" this way and that (200), pursuing the satisfaction of this or that appetite. And Madame de Vionnet, herself the victim of an arranged marriage, justifies her arranged marriage for her daughter on the basis of a "vieille sagesse" (239). Choices that reflect arbitrary whim or unreflectively adopted tradition command respectful non-interference, for they are the choices of

\footnotetext{
${ }^{54}$ Friedmann, supra note 8 at 629; Al-Tawil, supra note 8 at 372; Ralph M Cunnington, "The Inadequacy of Damages as a Remedy for Breach of Contract" in Charles EF Rickett, ed, Justifying Private Law Remedies (Oxford and Portland: Hart Publishing, 2008) at 133-134.

${ }^{55}$ Daphna Lewinsohn-Zamir, "Can't Buy Me Love: Monetary versus In-Kind Remedies” (2013) University of Illinois L Rev 151.
} 
free agents. But the content of such choices, because not expressive of moral agency, is a matter of indifference that no public authority has reason to further or promote.

However, not all choices have this character. Human beings have the capacity, not merely for free choice, but also for self-authorship - not merely for detachment, but for deliberative attachment. Human beings may reject the impulses they find in their makeup, reject social custom, and deliberatively adopt goals and commitments that reflect their own sense of what makes life worth living. They may deliberatively endorse a system of moral values and a conception of what it means to be a citizen; they may reflectively form emotional bonds with others, recognize ties to a particular community, choose careers, and organize their lives around particular interests and goals. The particular purposes and commitments that are chosen will be idiosyncratic. But the goal of self-authorship, shaping a life one can regard as one's own, is universal; it is the actualization of what is implicit in the idea that I can stand back from impulse and custom and choose for myself.

All this poses a challenge to the arguments in favour of adopting an abstract conception of moral agency. The first argument for adopting such a conception was that the process of abstraction revealed our capacity to choose and so our freedom and dignity as moral agents. But now we might notice that this freedom and dignity, as a bare capacity for detachment from wants and ends, lacks any worldly reality. Yet law purports to be authoritative for real human beings, not philosophical abstractions, and so the freedom and dignity we care about must be realized freedom and realized dignity. We therefore cannot abstract from the concrete lives of human beings and we cannot be indifferent to their efforts to lead lives of their own.

The second argument for adopting an abstract standpoint was that it alone provided a basis for equality among human beings in the sense of providing a public standpoint that all 
could share. But now it might be objected that abstract agency shuts out the perspective of the determinate individual who leads a life of commitment and reflective attachment to particulars and so is not a perspective the determinate individual can share; in that sense, the perspective of abstract agency is partial rather than universal. Finally, the argument for abstracting from all conceptions of the good was to leave each individual free to form her own conception of the good. But there is no tension between that idea and the recognition of self-authorship as an objective good; after all, self-authorship is just the realization of what is implicit in the idea that each person is a free moral agent, capable of originating ends rather than merely responding to external forces.

These counter-arguments show, however, that the conception of the abstract moral agent requires a supplement, not that it should be overthrown. We can show that this is true by considering what is lost if the abstract moral agent is simply rejected in favour of the selfauthoring moral subject. Moral agency, as the abstract capacity for detachment present in each human being regardless of circumstance or moral development, is the only conception of agency that provides a basis for equal and universal human worth. This is because self-authorship, in contrast to the capacity for detachment, is a goal, an ideal. Some will succeed in realizing this ideal whereas others will fail at it. Some human beings are in the grip of addictions or obsessions or delusions; some unconsciously repeat patterns of self-harming conduct, while others blindly adhere to the social or religious traditions into which they are born. Thus, self-authorship, though a conception of freedom, cannot be a conception of equal freedom - for human beings are not equally self-authoring. Taken alone, the norm of self-authorship can see nothing wrong with subordinating those who have failed to become the authors of their own lives to those have succeeded; taken on its own, the norm of self-authorship would permit the unilateral sacrifice of 
Madame de Vionnet — who is passive before the aristocratic tradition — for the sake of Chad's flourishing. If we think that human beings and not just successfully autonomous human beings have rights, we cannot do without the abstract conception of moral agency with which we began. Self-authorship may be our agency's perfection, but the sheer capacity for detachment must be its basis.

I suggest that this understanding of moral agency sheds light on the contractual remedy. Although we begin by treating the subject of contract as indifferent between contractual performance and a sum of money that represents the performance's financial value, we can now recognize that this depends on the assumption that all the subject's choices are arbitrary, that all material objects are properly regarded as undifferentiated means, and that any concrete attachment could only reflect an unfree fixation. There will be cases, however, that reveal this assumption as overbroad. In these cases, the thing bargained for - whether object or service will appear as a deliberative commitment, a reflective and therefore free attachment expressive of the subject's realized agency. It will occupy an important place in the subject's life plan such that he or she has a special interest in the performance and not merely in the performance's market value. If the thing that occupies this place in the promisee's life plan is a unique object that can only be supplied by the promisor — a collector's item or a particular residence - this is a case for specific performance. If the thing that figures importantly in the promisee's life plan may be supplied by someone other than the promisor, this is a case for damages measured by the cost of cure.

It is important to be clear that I am not suggesting that the availability of a performance remedy depends on the court's determination that the thing bargained for is objectively valuable. I am not suggesting that a court ask itself whether family farms or brands of pipe are worthwhile 
attachments. Rather, I am suggesting that the availability of a performance remedy depends on the court's determination that the attachment to the thing promised is deliberative rather than capricious, part of a life plan and not a passing whim. Where the attachment to the thing promised is an aspect of a thought-out scheme of commitments, recognizing the special interest in performance protects the good of self-authorship and so shows concern for the realized agency of the concrete individual. I suggest that Peevyhouse is a case of this kind.

In Peevyhouse, what appeared from the perspective of the abstract moral agent as an unfree attachment to a particular piece of land is, from the perspective of the self-authoring moral agent, a life plan. The Peevyhouses organized their lives around this piece of land - they built their home on it, cultivated it, used it as pasture; it was their life's work. ${ }^{56}$ What from the perspective of abstract agency was an agreement about the exchange value of coal extraction is, from the perspective of a subject immersed in a life plan, an agreement to allow coal extraction in exchange for royalties and the return of the land to usable condition. To recognize the Peevyhouses's right to the restored land is therefore not to treat them as passively tied to some object but rather to support their capacity for self-authorship, their ability to shape lives they can view as their own.

Of course, the Peevyhouses are not the only actors in this story. There are also the owners of the mining company. If we are going to preserve the idea, generated by the abstract conception of human agency, that human beings are equal and that no one can be forced to serve another, we cannot regard the interaction between the Peevyhouses and the mining company solely from the Peevyhouses' perspective; we cannot, like Strether in Paris, immerse ourselves in

\footnotetext{
${ }^{56}$ Maute, supra note 7 at 1356.
} 
their point of view and rest with the fact that the land in question was especially important to them. Critics of damages measured by financial loss have made this mistake. They have simply asked whether damages measured by financial loss will satisfy the subjective preferences of the plaintiff. ${ }^{57}$ But to end the inquiry there would unilaterally subordinate the owners of the mining company to the private perspective of the Peevyhouses. Others have recognized this problem and argued that the plaintiff's pro tanto entitlement to the cost of cure may be overridden if such damages would be unduly burdensome for the defendant ${ }^{58}$ However, this solution has the same problem in reverse. To deny the Peevyhouses what they are entitled to because it would be very hard on the defendant is to unilaterally subordinate the Peevyhouses to the private perspective of the mining company.

To avoid subordinating either party to the self-interest of the other, we have to ask a further question, but it is not whether the payment of cost of cure damages would be a heavy burden. It is rather the following: did the mining company reasonably know of the Peevyhouse's special interest in performance and can it therefore be assumed to have altered its price accordingly? ${ }^{59}$ This is the question that reconciles concern for the Peevyhouses' self-authorship with respect for the equal free choice of the owners of the mining company. This is the question that shows that even as we acknowledge the normative claims of self-authorship, we treat respect

\footnotetext{
${ }^{57}$ Webb, "Justifying Damages," supra note 8 at 160 (arguing that compensation for loss ought to be based on the plaintiff's subjective preferences, tastes, and goals); Eisenberg, supra note 24 at 1028 (arguing that the question at hand should be "promisee-centred").

${ }^{58}$ Smith, supra note 8 at 104; Al-Tawil, supra note 8 at 369; Chomsky, supra note 24 at 1499.

${ }^{59}$ It might be thought that the answer to this question is the full answer to whether cost of performance ought to be awarded and that we need not bother asking whether the thing bargained for figured importantly in the plaintiff's life plan. But this suggestion assumes that the parties to a contract can determine the remedy for breach, an assumption I criticized in footnote 30 . What determines whether and when cost of performance is an appropriate remedy is a persuasive theory of the contract remedy, not the parties, and that theory also determines the relevance of what the defendant reasonably knew. According to the theory I have proposed, a court's concern for self-authorship justifies cost of performance, but this remedy cannot come at the expense of the defendant's abstract freedom of choice that is the precondition of self-authorship. This is the only relevance of what the defendant reasonably knew.
} 
for free choice as a fundamental limit on the realization of that goal. After all, self-authorship is only possible for free moral agents capable of choice and responsibility and so it cannot be permitted to swallow the conception of moral agency that is its basis.

In Peevyhouse, the answer to the question of whether the mining company reasonably knew of the special importance of the remedial work seems to be yes. The Peevyhouses rejected the company's offer of an upfront $\$ 3000$ payment for any surface damage that might occur and instead insisted upon a promise that the remediation work be done. ${ }^{60}$ Thus, if the judge were to force the company to pay the cost of restoring the Peevyhouses's land, the owners of the mining company could not complain that they were being forced to serve the Peevyhouses' interest in self-authorship unilaterally or support the Peevyhouses' ends. The mining company knew of the special interest in performance and reduced its payment to the Peevyhouses accordingly. The argument for awarding the Peevyhouses the cost of cure is thus that the restoration of the land was an important aspect of the Peevyhouses' life plan and the owners of the mining company can reasonably be assumed to have known this.

Consider now how this analysis applies to Jacob \& Youngs. We begin from the assumption that Kent is indifferent between a house with Reading pipe and a house of equal market value with different but qualitatively comparable pipe. We make an exception, however, if Kent can show that he had a special interest in performance. Showing a special interest in performance entails two things. First, it entails showing that the interest at stake is not the one assumed by the abstract conception of agency—the interest in increasing one's all-purpose means; for that interest is satisfied by a sum of money representing one's financial loss. Rather,

\footnotetext{
${ }^{60}$ Maute, supra note 7 at 1358 and 1365.
} 
Kent must show an attachment to the specific thing promised. Second, if Kent claims an attachment to the specific thing promised, he must show that his attachment flows from a deliberative commitment and not to a passing whim. Thus, he must show that he wanted this brand of pipe, for example, because of a historical connection to this particular company or a particular interest in supporting its business. Moreover, if Kent could demonstrate that his attachment to Reading pipe was the product of a deliberative commitment, he must also show that the builder reasonably knew of this commitment.

Kent fails on all these conditions. There is no evidence of any special attachment to the Reading factory, still less of a deliberative one ${ }^{61}$; what information we have points to a capricious and obstinate insistence upon a particular specification. Moreover, even if there was a deliberative attachment to the factory, there is no evidence that this was communicated to the builder or was otherwise reasonably known to him. The builder reasonably believed that the reference to Reading was a reference to pipe of a certain quality - wrought iron as opposed to steel. $^{62}$

The foregoing account of the difference between Peevyhouse and Jacob \& Youngs derives from a theory of contract remedies that recognizes the normative claims of selfauthorship while treating respect for free choice (self-authorship's basis) as fundamental. We award damages measured by cost of cure only when the thing promised figures importantly in the plaintiff's life plan and where that special attachment was reasonably known to the defendant. In so doing, we treat the subjects of contract law as determinate human beings with

${ }^{61}$ Danzig, supra note 53 at 120.

62 Ibid at 121. 
deliberative attachments without unilaterally subordinating one to the needs and values of another.

\section{Conclusion}

Reading the recent literature on contract theory might leave one with the impression that moral accounts of contract law must be critical of the remedy that vindicates the compensation interest in the usual case and the performance interest only in the exceptional one, leaving a defense of the law to economists. Against this view, I have argued that there is a moral justification for the traditional remedy, one that rests on a conception of agency that rivals the conception of agency implicit in its moral critique. To make the argument, I have brought forward Henry James's The Ambassadors because it shows us the lived implications of the competing conceptions of moral agency, and so illuminates their value and their limitations. Through the novel, we are drawn toward a complex picture of moral agency, one that justifies compensation for financial loss as the normal remedy for breach while explaining the exceptional character of remedies that approximate performance. ${ }^{363}$ The normal remedy envisages the independent moral agents personified by Mrs. Newsome of Woollett—agents capable of detachment from objects and commitments and whose equal dignity rests on this universal capacity. Remedies that approximate performance are consistent with this conception of human independence, and indeed provide a necessary supplement to it, only where, as with Strether in Paris, the attachment to performance flows from a deliberative and therefore selfauthored commitment or project. However, forcing the defendant to serve the plaintiff's

\footnotetext{
63 I think that this conception of moral agency resolves many other puzzles in contract law- for example, the place of disgorgement as a remedy for breach of contract, the place of damages for mental distress, the proper understanding of the tort of inducing breach of contract, as well as the nature of the contractual obligation - but a discussion of these is of course beyond the scope of this paper.
} 
idiosyncratic commitment coheres with the equality of the parties secured by the detached standpoint only if the defendant knew or ought to have known of the plaintiff's commitment and so can be assumed to have extracted a price for serving it. The exploitation of Madame de Vionnet by Chad illustrates the problem with treating self-authorship as a stand-alone conception of dignity, leaving out detachment. 